\title{
IAMJ
}

INTERNATIONAL

AYURVEDIC

MEDICAL JOURNAL

ISSN: 23205091

Impact Factor: 5.344

\section{MANAGEMENT OF IUGR THROUGH AYURVEDA: CASE REPORT}

\author{
Reetu Pandey ${ }^{1}$, Seema Shukla ${ }^{2}$ \\ ${ }^{1}$ Assistant professor, SAM College of Ayurveda, Raisen (M.P.), India \\ ${ }^{2}$ HOD PG Dept of PTSR, Paprola, Kangra (H.P.), India
}

Corresponding Author: vdreetupandey@gmail.com

https://doi.org/10.46607/iamj3808112020

(Published online: November 2020)

Open Access

(C) International Ayurvedic Medical Journal, India 2020

Article Received: 23/10/2020 - Peer Reviewed: 30/10/2020 - Accepted for Publication: 01/11/2020

Check for updates

\section{ABSTRACT}

Intrauterine growth restriction refers to a condition in which a fetus is unable to achieve its genetically determined potential size. Thus, an IUGR fetus should have grown bigger, if growth-inhibiting factors had not been present in embryonic life. This case study is about a 22-year-old primigravida whose ongoing pregnancy was uneventful until her seventh month. She was visiting Civil Hospital Baijanath (H.P.) for regular antenatal check-ups. On her seventh-month routine visit to the hospital, she was clinically diagnosed with intrauterine growth restriction.

She was treated with allopathic medicines, but her condition deteriorated then she visited gyne OPD of Ayurvedic medical College Paprola on the 33rd week of pregnancy and was treated with Ayurvedic formulation. She was given granules of Garbhshoshahara yoga described in Garbhashaygata Vata chikitsa in Ashtanga Sangrah.

Keywords: Garbh Shosh, Intrauterine Growth Restriction (IUGR), Garbhkshaya, Garbhashoshahara yoga.

\section{INTRODUCTION}

The concept of fetal well-being has gained importance in conventional science in the recent era, but it is the prime concern of Ayurveda. Intrauterine growth restriction is said to be present in those fetuses whose weight is below the 10th percentile of average gestational age. Growth restriction is difficult to diagnose and equally difficult to define. Birth weight percentile determines growth based on adjustments for the period of gestation, maternal height, maternal weight, race, birth order, and gender. There is 
increased neonatal morbidity and mortality due to birth asphyxia, respiratory distress, meconium aspiration, hypothermia, hypoglycemia, and neonatal sepsis.

In Ayurveda, several disorders are described with the explanation of fetal growth restriction such asUpavishtaka, Nagodara, Vatabhipannagarbha, Garbh Shosha. Emaciation is mainly caused by Vata Dosha. This is the main reason behind choosing Garbhashoshahara yoga because it contains Madhur Ras, Sheeta Virya, and Rakta Prasadan herbs for the pacification of Vata Dosha

\section{Case Report: -}

22-year-old primigravida who was under treatment for an antenatal check-up at Civil Hospital Baijnath when she was detected with reduced symphysis fundal height which was like 25 th week when she visited there at 28th week. After a clinical diagnosis, she was managed with modern medicine and advised to take a protein-rich diet, but her condition wasn't improved. After 4 weeks of treatment, she went for an ultrasound scan at the 33rd week of gestational age. The ultrasound suggests the fetus's intrauterine growth restriction. Then she came to Prasuti Tantra and Stri Rog OPD of Ayurvedic Hospital Paprola for further treatment. As she was taking modern medicines and was not responding to those treatments, so we started Ayurvedic treatment i.e. Garbhashoshahara yoga granules 5 grams twice daily with milk. Alongside, she was given Amalaki powder 3 gram twice daily with honey.

After 4 weeks of treatment, we advised the ultrasound scan. In this scan fetal weight was improved drastically and reached $2870 \mathrm{gm}$. At 39 weeks 5 days, she delivered a healthy male baby of weight $3.10 \mathrm{~kg}$ with an APGAR score of 10/10 at $1 \mathrm{~min}$.

Treatment - Garbhashoshahar yoga 5 grams twice daily with milk, Aamalki churna 3 grams twice daily, coconut water, and iron- calcium.

\section{Garbhashoshahara yoga content-}

\begin{tabular}{|l|l|}
\hline Drug & Botanical name \\
\hline Sariva & Hemidesmus indicus \\
\hline Madhuyashti & Glycyrrhiza glabra \\
\hline Gambhari & Gmelina arborea \\
\hline Sita & Saccharum officinarum \\
\hline
\end{tabular}

Personal history: -

\begin{tabular}{|l|l|}
\hline Appetite & Good \\
\hline Diet & Mixed type of diet \\
\hline Bowel & Constipation on and off \\
\hline Micturition & Increased frequency \\
\hline Sleep & Disturbed \\
\hline
\end{tabular}

\section{Menstrual history: -}

\begin{tabular}{|l|l|}
\hline Menarche & 12 years \\
\hline Interval & $28-34$ days \\
\hline Duration & $4-5$ days \\
\hline Amount & 3 pad per day \\
\hline Clots / Pain & $+/+++$ \\
\hline
\end{tabular}

\section{Obstetric History: -}

Gravida 1, Para 0, Abortion 0, Live 0

Last menstrual period- 24 May 2015 
Expected date of delivery - 28 February 2016

Marital history- Married since 14th January 2015

Observations: -

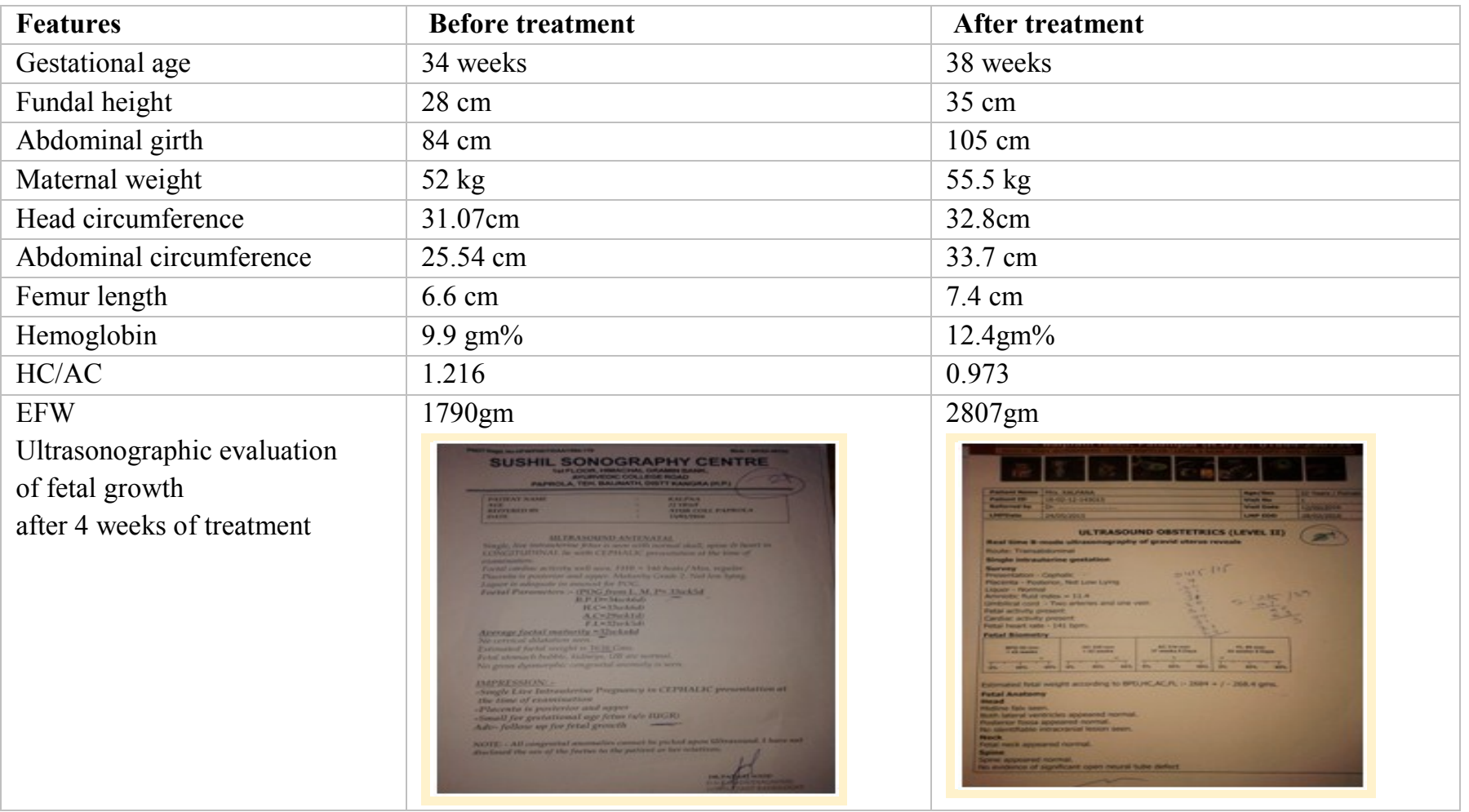

\section{DISCUSSION}

Intrauterine growth restriction was correlated with Garbh Shosha. As per Samprapti (pathogenesis), it was clear that Garbhashosh (IUGR) is due to Vata predominance with Pitta-Kapha Anubandha (stipulation) and Garbhashoshahar Yoga having Tridosha Shamaka property. All drugs of garbhashoshahara yoga have Vata-Pitta Shamaka and Saptadhatu Prashadaka property due to Madhur Rasa. Ojovardhaka, and Vata Shamaka due to guru and Snigdha Guna. Pitta Shamaka and Kapha Vardhaka due to Sheeta veerya and Madhur vipaka. The Rasayana effect of Garbhashoshahar yoga causes better dhatu poshana in the mother and in the fetus. Due to anti-inflammatory properties, it removes the congestion of vascular endothelium and placenta. So, improves placental circulation. It inhibits platelet aggregation, thus prevents clot formation in placental vessels. In addition, all the above mechanisms improve fetal growth restriction.

\section{CONCLUSION}

Garbhashoshahar Yoga is effective, tolerable in fetal growth restriction. The safety and efficacy of the drug were confirmed by the fact that all women showed maternal and fetal weight gain without any complication after the administration of the drug. From the observation, it can be concluded that Garbhashoshahara Yoga was effective in improving the Intra Uterine Growth Restriction. The case study helps us to understand the efficacy of Ayurvedic drugs in such a disease where modern medicine has limited effect and it will open scope for further research in this field.

\section{ACKNOWLEDGMENT}

First and foremost, my heartfelt thanks to the pregnant woman who, in spite of being a victim of the disease, was kind enough to extend her co-operation which formed the basis of this study. I would like to express my immense gratitude to Prof.(Dr.) Y. K. Sharma, 
Principal R.G.G.P.G Ayurvedic college and hospital Paprola, Dr. Seema Shukla, HOD of PTSR Dept., Prof. (Dr.) Eena Sharma, former H.O.D PTSR Dept, Dr. Soni Kapil, Reader PTSR Dept., Dr. Rakesh Sharma, HOD Bal Roga Dept. for their support and motivation.

\section{REFERENCES}

1. K. C. Chunekar, edited by G.S. Pandey, Bhavaprakasha of Bhavamishra commentary, Chaukhambha Bharati Academy, Varanasi, 2004, Page No. 393.

2. K. C. Chunekar, edited by G.S. Pandey, Bhavaprakasha of Bhavamishra commentary, Chaukhambha Bharati Academy, Varanasi, 2004, Page No.65.

3. K. C. Chunekar, edited by G.S. Pandey, Bhavaprakasha of Bhavamishra commentary Chaukhambha Bharati Academy, Varanasi, 2004, Page No.392.

4. D. C. Dutta, Textbook of obstetrics, Edited by Hiralal Konar, Chapter no 31 Low Birth Weight Baby, New Central Book Agency (P) Ltd London, ed.7th (2011); p461.

5. Polani PE. chromosomal and other genetic influences on birth weight variation. In: Elliot K, Knight J(Eds). Size at birth. London: Associated Scientific Publishers, 1974.

6. Pt. Shri. Brahma Shankara Mishra, Bhavaprakasha of Bhavamishra with Vidyotini Hindi Commentary, Chaukhambha Sanskrit Samsthana, Varanasi, 5th edition, 1993.

7. Intrauterine Growth Retardation - A Review Article by Srinivas Murki and Deepak Sharma.

8. P. V. Sharma, Nibandhasangraha of Dalhana on Sushruta Samhita, 1st Ed., Chaukhambha Vishwabharati Oriental Publishers (2002), Varanasi, p162.

9. Pandit Hari Sadashiv Shastri, Ashtang Hridaya with commentary by Arundatta and Hemadri, Choukhambha Surbharati Prakashan, Varanasi,2015, Page No. 380.

10. P. V. Sharma, Dravyaguna Vijnana (Vol-2), Reprint 2015.Varanasi, Chaukhamba Bharati Academy.

11. Vaidya Yadavji Trikamji Acharya, Charaka Samhita with Ayurved Deepika commentary by Chakrapanidatta, Munshiram Manoharlal Publishers Pvt. Ltd. 2011, Page NO. 345.

\section{Source of Support: Nil \\ Conflict of Interest: None Declared}

How to cite this URL: Reetu Pandey \& Seema Shukla: Management Of IUGR Through Ayurveda: Case Report. International Ayurvedic Medical Journal \{online\} 2020 \{cited November, 2020\} Available from: http://www.iamj.in/posts/images/upload/5185_5188.pdf 